\title{
ПРОБЛЕМА ВЫЯВЛЕНИЯ СУЩНОСТИ «ГОСУДАРСТВА ПРАВДЫ॥ Н. Н. АЛЕКСЕЕВА В СВЕТЕ ПРЕДСТАВЛЕНИЙ О КОММУНИЗМЕ НИКОЛАЯ БЕРДЯЕВА И ЭРИХА ФРОММА
}

\section{THE PROBLEM OF IDENTIFYING THE ESSENCE OF THE "STATE OF TRUTH» \\ BY N.N. ALEKSEEV IN THE LIGHT \\ OF IDEAS ABOUT COMMUNISM BY NIKOLAI BERDYAEV AND ERICH FROMM \\ K. Cheprasov}

Summary: The article analyzes the concept of the "State of truth» by N.N. Alekseev from the point of view of revealing its essence in the context of ideas about communism by N.A. Berdyaev and E. Fromm. The paper concludes that N.N. Alekseev incorrectly interpreted the essential features of communism, as well as its historical role in the life of the Russian people, which led to the separation of the concept of Alekseev from reality.

Keywords: Alekseyev, State of Truth, Communism, Marxism, Eurasianism.

\author{
Чепрасов Константин Викторович \\ К.ю.н., доцент, ФГБОУ ВО «Алтайский государственный \\ университет» (Барнаул) \\ kkimp@yandex.ru
}

Аннотация: (татья посвящена анализу концепции «Государства правды» Н.Н. Алексеева с точки зрения выявления ее сущности в контексте представлений о коммунизме Н.А. Бердяева и Э. Фромма. В ходе работы делается вывод 0 том, что Н.Н. Алексеев неверно интерпретировал сущностные черты коммунизма, а также его историческую роль в жизни русского народа, что привело к отрыву концепта Алексеева от реальности.

Ключевые слова: Алексеев, государство правды, коммунизм, марксизм, евразийство.

онная интеллигенция, оказавшаяся после революции на Западе.

Не согласившись с большевистской революцией и коммунистическими идеалами, эмигранты, разочарованные при этом в русской монархии периода Николая II, начали искать какие-либо альтернативные концепты развития России. Идеи Н.Н. Алексеева о «Государстве правды» в этой связи, являются характерным примером таких попыток. Именно в идеях Алексеева крайне рельефно отражается та двойственность и внутренняя противоречивость русских мыслителей-антикоммунистов, которые критикуя большевизм, в сущности, выдвигали аналогичные большевистским концепции. Различие, пожалуй, состояло лишь в том, что в отличие от большевиков русские эмигранты так и не смогли проникнуть В тайну чаяний и надежд русского народа.

Пожалуй, одним из немногих русских мыслителей, которые смогли по настоящему осмыслить суть большевистской революции и коммунизма, был Н.А. Бердяев. В этой связи крайне актуальным является сопоставление идей Алексеева, мечтавшего о «Государстве правды», с ражает ту экзистенциальную и концептуальную растерянность, которые испытывала русская эмиграци-

Исследование выполнено при финансовой поддержке фонда грантов Президента РФ для молодых российских ученых кандидатов наук, Проект № МК-483.2020.6 «Евразийская альтернатива государственно-правового развития России: генезис, содержание, современное прочтение» 
анализом Бердяева, посвященным специфике русского коммунизма.

В основе идеи «Государства правды» Алексеева, считает А. Величко, лежит представление о кардинальном различии культурных кодов Запада и Востока. Величко отмечает, что на Западе «индивид понимается в качестве самодостаточной и самоизолированной единицы, чьи отношения с себе подобными строятся на условии, договоре». Автор указывает, что «право в этом случае рационализируется и утрачивает органическую связь с нравственностью и нравственным идеалом». Совершенно иным образом дело обстоит «в органических отношениях традиционных культур Востока, где превалирует нравственное начало, речь идет о праве как способе достижения социальной справедливости, социальной правды» [13].

Н.Н. Алексеев действительно в центр своей концепции идеального государства выдвигал именно морально-нравственные основания. Однако главная ценность концепции Алексеева заключается в том, что в отличие от многих других русских мыслителей, он не пренебрегал социально-экономической стороной государственной жизни, признавая успех большевиков на этом поприще. В частности, по поводу большевизма Алексеев отмечал, что «как и во всяком политическом строе, в нем есть много несовершенств, но, возможно, что в нем при внимательном и беспристрастном взгляде откроются и некоторые положительные стороны... Как бы мы не оценивали российскую революцию, одно несомненно: в ней проявилось громадное напряжение русского народа в искании политической и социальной правды» [2, с. 292].

Именно социальная справедливость, как максима существования большевизма, является, по мнению Алексеева, ключевой позитивной чертой коммунистической идеи. Более того Алексеев оказывается в одном с большевиками лагере с точки зрения безапелляционной критики капитализма, как некоего прирожденного зла, угрожающего человеческой личности. Алексеев пишет: «Сила советского государства заключается в том, что оно своей целью поставило решительную борьбу с капитализмом, объявило себя, таким образом, некоторым «государством правды» и заставило многих поверить, что оно действительно есть «государство правды»» [2, с. 309].

Однако Алексеев категорически не согласен с той правдой, которая составляет суть большевистской, коммунистической идеи. Примечательно, что именно в части критики коммунизма концепция Алексеева представляется наименее объективной, поскольку понимание Алексеевым коммунизма является предельно упрощенным.

Алексеев обрушивается на коммунизм и марксизм, упирая на его аморализм и безнравственность, постоянно подчеркивая разрушительную стихию этой идеологии. Так, Алексеев утверждает, что «Марксизм, кроме того, стремится вытравливать из душ людей все те высшие ценности, на которых строилась общественная жизнь, - идею религии, нравственности, социального мира и т.п. заменив их идеями классового интереса и материального благополучия» [2, с. 283].

Более того Алексеев явно стоял на позиции, крайне характерной именно для западных интеллектуалов, рассматривающих коммунистическое общество в качестве серой массы лишенных индивидуальности элементов тоталитарной системы. Интеллектуальное чутье здесь изменяло Алексееву, поскольку он не желал замечать тех колоссальных усилий, которые предпринимают большевики для трансформации общества из отсталого традиционного в современное, модернизированное.

Например, Алексеев отмечал: «На место буржуазного общества коммунисты хотят поставить столь централизованное общество, которое потеряет характер государства и превратится в чисто технический аппарат, в машину» [2, с. 298]. В противовес этому Алексеев выдвигал свою альтернативную концепцию истинно народной идеологии, которая должна прийти на смену марксизму. В частности, он писал: «Россия истинно вылечится только тогда, когда на смену привитой ему дурной и разлагающей марксистской идеологии из самих недр народных возникнет идеология новая, живая и спасительная» [2, с. 289-290].

Однако в то же время, Алексеев не говорил ничего внятного относительно характеристик этой идеологии, в сущности, отождествляя ее с религией. Проблема же заключалась в том, что Алексеев, как и многие интеллигенты-эмигранты, отказывался посмотреть в лицо тому реальному русскому народу, который революцию с упоением принял, причем принял в том числе и ее антирелигиозный характер. Виной же последнему аспекту, кроме атеистической направленности марксизма, очевидно было вырождение и дискредитация религиозных институтов Российской Империи. Весьма симптоматично, с какой легкостью Священный Синод принял отречение царя от трона и указывал приходам по всей стране молиться за буржуазное Временное правительство [3, с. 522].

Народный характер большевизма гениально разглядел современник Алексеева - Н.А. Бердяев, который указывал, что к началу 20 века «иллюзии революционного народничества были изжиты, миф о народе-крестьянстве пал. Народ не принял революционной интеллигенции. Нужен был новый революционный миф. И миф о народе был заменен мифом о пролетариате» [4, с. 88]. Причем Бердяев отмечает, что «в мифе о пролетариате по-новому восстановился миф о русском народе. Произошло как бы 
отождествление русского народа с пролетариатом, русского мессианизма с пролетарским мессианизмом. Поднялась рабоче-крестьянская, советская Россия» [4, с. 88]. В итоге, считает Бердяев, «произошло как бы отождествление двух мессианизмов, мессианизма русского народа и мессианизма пролетариата» [4, с. 88].

Алексеев чувствовал то, что Бердяев так четко отразил в своей работе, однако подняться на рефлексивный уровень Алексеев так и не смог. Например, мыслитель отмечал, что «большевистская политика имела успех оттого, что смогла внушить народам веру в ту же великую социальную миссию России. И большевистская Россия служит для многих символом свободы, считается покровительницей угнетенных, предвестницей будущего земного рая» $[2$, с. 294]. Однако Алексеев в конечно счете однозначно констатировал, что увлечение русским народом коммунизмом - это явление наносное и временное, которое не исходит из глубин народного сознания.

Гораздо более трезво смог разглядеть в коммунизме те черты, которые так привлеки русский народ, Бердяев. Он писал: «Марксизм есть также учение об избавлении, о мессианском призвании пролетариата, о грядущем совершенном обществе, в котором человек уже не будет зависеть от экономики, о мощи и победе человека над иррациональными силами природы и общества. Душа марксизма тут, а не в экономическом детерминизме» [4, с. 80].

Более того Бердяев прямо констатировал, что марксизм призван бороться именно за сохранение человеческой личности в угрожающем ей мире капиталистической дегуманизации. По мысли Бердяева, «Маркс открывает в капитализме процесс дегуманизации, овеществления человека» $[4$, с. 80].

Бердяев также подмечает такой аспект учения Маркса, который и сегодня для многих исследователей является достаточно нетривиальным. В частности, он пишет: «Пролетариат должен бороться против овеществления человека, против дегуманизации хозяйства, должен обнаружить всемогущество человеческой активности. Это совсем другая сторона марксизма и она была сильна у раннего Маркса...В марксизме есть элементы настоящей экзистенциальной философии» [4, с. 82].

В конечном счете, Бердяев признает, что «Марксизм не есть только наука и политика, он есть также вера, религия». Как представляется именно этот аспект учения Маркса и большевистской революции не смог осмыслить Алексеев, что в итоге сказалось на его концепции «Государства правды».

Дело в том, что Алексеев будущее России видел именно в возникновении новой, альтернативной коммунизму идеологии. Он писал в этой связи: «Россия истинно выле- чится только тогда, когда на смену привитой ему дурной и разлагающей марксистской идеологии из самих недр народных возникнет идеология новая, живая и спасительная» [2, с. 290]. Проблема же здесь заключалась в том, что коммунизм, как это наглядно показал в своей работе Бердяев, именно и вышел из недр народного сознания, был созвучен глубинным чаяниям русского народа.

Парадокс Алексеева заключается в том, что, яростно отрицая большевизм и коммунизм, он, по сути, не предлагает ничего нового, чего бы не предполагала коммунистическая идея. В частности, Алексеев яростно критикует капиталистическое устройство, при котором «одни граждане - и их неоспоримое большинство - должны нести многочасовой, бессмысленный, отупляющий, духовно-уничтожающий труд, а другие - наслаждаться продуктами этого труда, и по большей части вовсе не в духовных целях, а просто в целях весьма не высоких, а иногда и прямо низменных удовольствий!» [2, с. 308]. «Государство правды» по Алексееву - это такое устройство общества, которое, освободит труд от экономической эксплуатации. И в этом идеи Алексеева никак не противоречат идеям большевиков. И хотя Алексеев критикует большевистские методы, альтернативных методов Алексеев принципиально не озвучивает, поскольку в реалиях России начала 20 века эти методы по определению не могли быть лишенными каких-либо доз принуждения, насилия и авторитаризма.

Симптоматично, что идеи Алексеева вызвали в итоге критику со стороны его учителя П.И. Новгородцева, который с упреком заявил, что его ученик «отступил от русской традиции, согласно которой право нужно сливать с нравственностью» [1, с. 215]. При этом Алексеев не принимал и западной, буржуазной позитивистской рассудочности, не отрицая при этом значимость разума [6, с. 70]. Следует предположить, что не в последнюю очередь именно эта особенность мировоззрения Алексеева одновременно и притягивала его к идеям большевиков и яростно отрицала их.

В итоге, как отмечает М.А. Гусарова, Алексеев отказался от противоположных друг другу стратегий в выборе вектора исторического развития России, предприняв предпринял попытку поиска «золотой середины» между западнической и славянофильской позициями [5]. Однако Алексеев исходил из ложной посылки о том, что русский коммунизм и марксизм являются по своей сути западническими идеями, и не смог увидеть в них подобно Бердяеву глубокой созвучности русской народной жизни. Все это не могло не повлиять на адекватность восприятия Алексеевым реального социально-духовного климата в России.

В этой связи нельзя не вспомнить слова В.И. Ленина, 
довольно точно подметившего «ахиллесову пяту» русской интеллигенции (которая в эмиграции лишь усилилась). Обсуждая типичные черты русского интеллигента на примере Л.Н. Толстого, Ленин так описывает психологический портрет «толстовца»: «истасканный, истеричный хлюпик, называемый русским интеллигентом, который, публично бия себя в грудь, говорит: «я скверный, я гадкий, но я занимаюсь нравственным самоусовершенствованием; я не кушаю больше мяса и питаюсь теперь рисовыми котлетками». С одной стороны, беспощадная критика капиталистической эксплуатации, разоблачение правительственных насилий, комедии суда и государственного управления, вскрытие всей глубины противоречий между ростом богатства и завоеваниями цивилизации и ростом нищеты, одичалости и мучений рабочих масс; с другой стороны, — юродивая проповедь «непротивления злу» насилием»» [7, с. 209]. Несмотря на хлесткие эпитеты, употребляемые Лениным, изображенный им образ русского интеллигента весьма репрезентативен, в том числе и в случае с Н.Н. Алексеевым.

Действительно, с одной стороны Алексеев почти как заядлый марксист критикует капиталистический строй, указывая, что «Капитал, возникнув часто как премия способности, становится наследственным преимуществом; бедность же, являющаяся часто расплатой за неспособность и леность, также унаследуется теми, кто в этих качествах не является повинным. Таким образом, родится социальный строй... ставя в неравное положение прирожденный талант наследственного пролетария и полную бесталанность владетелей капитала, наслаждающихся плодами своих отцов» [2, с. 320].

С другой стороны Алексеев демонстрирует поразительную близорукость и политическую растерянность, когда дело касается выработки какой-либо альтернативной модели организации общества. Так, ученый, предлагая свой вариант построения новой России, выдвигает формулу - «Россия с Советами, но без коммунизма», отмечая, что «русский народ... теперь... сам - хозяин и распорядитель. Если он не досмотрит, то кто же за него сделает. Коммунисты? Но ведь он не хочет коммунистов... Советы не могут не собраться в срок, как бы там коммунисты ни фокусничали; на выборы должны идти все до одного; выбирать организованно людей крепких, верных народному делу; наказывать им, чтобы в дальнейших выборах депутаты шли как стена, не поддавались никакому давлению. Будет это - исцелится Россия» [2, с. 358-359].

Наивность подобных рассуждений и главное их оторванность от реальной России, которая, как верно отметил Бердяев, увидела в коммунизме воплощение русского мессианства, как раз и отражает главный изъян концепции «Государства правды» Алексеева. Он не смог подобно Бердяеву увидеть, что «марксизм не есть только наука и политика, он есть также вера, религия. И на этом основана его сила» [4, с. 82]. В итоге же Алексеев обсуждал не реальный русский народ, а собственноручно созданную химеру. Алексеев упорно искал новую, живую, спасительную для России идею, однако так и не смог заметить, что для русского народа такой идеей стал именно квазирелигиозно переживаемый коммунизм.

Несмотря на это, Алексеев все же разгадал фундаментальный изъян советского общества, который спустя многие годы привел к краху государства. Мыслитель смог разглядеть в советском обществе нарывы мещанства, которые с каждым десятилетием лишь усиливались. Довольно пророчески звучат следующие слова Алексеева: «в советском государстве фактически вовсе не властвует рабочий класс, а деклассированная интеллигенция очень разнообразного национального состава, объявившая себя хранительницей интересов пролетариата. Эгоистическая и себялюбивая диктатура такой интеллигенции еще хуже, чем диктатура класса, ибо она вырождается в диктатуру наихудшей бюрократии» [2, с. 345].

Впрочем, эту же опасность осознавали и сами советские граждане. Не зря В.В. Маяковский обличал в своих стихотворениях «мурло мещанина», ужасаясь тому, что «Опутали революцию обывательщины нити» [10, с. 68]. О бюрократизации государства и отрыве управленческого аппарата от народа беспокоился и сам В.И. Ленин, написавший в этой связи статью «Как нам реорганизовать Рабкрин», в которой он предостерегал об опасности формирования в недрах советского общества «новой буржуазии», которая способна породить социальный раскол и навредить государству [8, с. 387-388].

Однако, несмотря на все изъяны концепции «Государства правды» Алексеева, наиболее значимым достоинством его теории является все же гуманистический пафос, связанный с требованием творческого восхождения человека. Сам Алексеев в этой связи писал, что «у человека, в сущности говоря, есть только одно неоспоримое право - это право на внутреннее, духовное развитие. Отрицание этого права уничтожает у человека качество быть человеком и делает нормальное развитие государства невозможным» [2, с. 317]. Капитализм же согласно мысли Алексеева неприемлем для России, прежде всего, потому, что этот строй способен погубить душу человека.

«Праведное государство» по Алексееву, имеет своей целью создание таких социально-экономических условий, которые будут направлены на обеспечение «духовного развития и духовной жизни» человека.

В то же время следует признать, что именно в этой своей самой сильной части концепции «Государства правды», Алексеев исходит из неверно понятой сущности 
учения Маркса. Относительно марксизма и коммунизма Алексеев утверждает следующее: «коммунистическое государство, следуя материалистической философии марксизма, познает один только вид освобождения - освобождение материальное, экономическое. Оно обещает дать всем людям в достаточном количестве хлеба, полагая, что остальное все приложится, если человек будет сыт. Да и прилагаться-то, в сущности говоря, нечему, так как марксистский коммунизм считает идеалом человека наиболее сытое, довольное и материально счастливое пребывание на нашей планете» [2, с. 309].

Это крайне распространенное и ныне заблуждение относительно реальных целей коммунистического общества весьма основательно развенчивает Эрих Фромм в своей статьей «Марксова концепция человека». Он замечает, что «Самым распространенным заблуждением является идея... согласно которой Маркс якобы считал главным мотивом человеческой деятельности стремление к материальной выгоде, к удобствам, к максимальному благосостоянию, «обеспеченности» своей жизни и жизни своей семьи... будто Маркс не проявлял никакого интереса к индивиду и не понимал духовных потребностей человека: будто его идеалом был сытый и хорошо одетый «бездушный» человек» [12, с. 577-578].

По мнению Фромма, основанном на анализе ранних работ Маркса, таких как «Экономико-философские рукописи 1844 года», «истинная цель Маркса состояла в освобождении человека от давления экономического принуждения с тем, чтобы он мог - и это главное - развиваться как человек (формировать себя как гармоничную личность). То есть главная забота Маркса - освободить человеческую личность, помочь человеку преодолеть утраченную гармонию с природой и другими людьми» [12, с. 579]. Фромм называет философию Маркса «духовным экзистенциализмом», направленным на «освобождение человека от такой формы труда, которая разрушает его личность, от такого труда, который превращает человека в вещь, который делает его рабом вещей» [12, с. 590].

Сам же Маркс однозначно писал: «Чем ничтожнее твое бытие, чем меньше ты проявляешь свою жизнь, тем больше твое имущество, тем больше твоя отчужденная жизнь...» [9, с. 602]. Более того, Маркс утверждает, что «Производство производит человека не только в качестве товара, не только человека-товар, человека с определением товара, оно производит его, сообразно этому определению, как существо и духовно и физически обесчеловеченное. - Аморальность, вырождение, отупение и рабочих и капиталистов. - Продукт этого производства есть товар, обладающий сознанием и самостоятельной деятельностью,.. человек-товар...» [9, с. 574].

Однако главная загвоздка здесь в том, что ряд ранних работ Маркса, например «Экономико-философские рукописи 1844 года» стали доступны западному читателю лишь в 1959 году, после публикации английского перевода этого труда, сделанного в СССР. В то же время нельзя не подметить, что данный факт не помешал сделать крайне прозорливые выводы Бердяеву.

В любом случае заблуждения Алексеева относительно сущности коммунизма, тем более сформировавшиеся у него в эпоху стремительной фашизации Европы, а значит и активной дискредитации на Западе, как Советского Союза, так и самого коммунизма, вполне объяснимы и понятны.

Можно предположить, что факт активной поддержки Алексеевым антифашистского Сопротивления в Югославии во время Второй Мировой войны, а также получения в 1945 году советского гражданства, свидетельствует о своеобразном примирении мыслителя с коммунизмом и советской Россией, пусть и частичном.

В конечном итоге следует признать, что Алексеевское идеальное «Государство правды», сущность которого должна была состоять в формировании таких социально-экономических условий, которые позволили бы человеку осуществлять духовное восхождение, в реальных условиях 20 века могло быть только коммунистическим, поскольку альтернативой коммунистическому раскрепощению и пробуждению высших творческих способностей человека были, либо фашистское расчеловечивание, либо капиталистическое потребительское прозябание.

\section{ЛИТЕРАТУРА}

1. Алексеев Н.Н. Из Царьграда в Прагу. Русский юридический факультет. Русские историки-эмигранты в Европе. М., 1991. - 350 с.

2. Алексеев Н.Н. Русский народ и государство. - М.: «Аграф», 1998. - 640 с.

3. Бабкин М.А. Святейший синод православной Российской церкви и свержение монархии // Вестник Санкт-Петербургского университета. История. - 2017. - Т. 62. - Вып. 3. - С. 522-544.

4. Бердяев Н.А. Истоки и смысл русского коммунизма. - М.: Наука, 1990. - 224 с.

5. Гусарова М.А. Проблема интегративного подхода к пониманию права и государства в философско-правовом творчестве Н. Н. Алексеева // Теория и практика общественного развития. - 2020. - № 1. URL: http://teoria-practica.ru/vipusk-1-2020/ (дата обращения: 29.10.2020).

6. Золкин А.Л. Феноменологическая методология познания права в философии русского евразийства // Вестник Академии экономической безопасности 
МВД России. - 2015. - № 3. - С. 69-71.

7. Ленин В.И. Полное собрание сочинений. Т. 17. - М.: Изд-во политической литературы, 1968. - 655 с.

8. Ленин В.И. Полное собрание сочинений. Т. 45. - М.: Изд-во политической литературы, 1970. - 729 с.

9. Маркс К., Энгельс Ф. Из ранних произведений. - М.: Госполитиздат, 1956. - 689 с.

10. Маяковский В.В. Сочинения в одном томе. - М.: ОГИЗ, 1941. - 536 с.

11. Рюдигер Петер Хартмут. Иван Ильин и фашизм // Альтернативы. - 2012. - № 4. URL: http://www.intelros.ru/readroom/alternativi/a4-2012/18240-ivan-ilini-fashizm.html (дата обращения: 29.10.2020).

12. Фромм Э. Концепция человека у Карла Маркса // Маркс. К. Экономико-философские рукописи 1844 года и другие ранние философские работы. - М.: Академический проспект, 2010. - 775 с.

13. Хронос: всемирная история в интернете. URL: http://www.hrono.ru/biograf/bio_a/alekseev_nn.html (дата обращения: 29.10.2020).

(c) Чепрасов Константин Викторович (kkimp@уandex.ru)

Журнал «Современная наука: актуальные проблемы теории и практики»

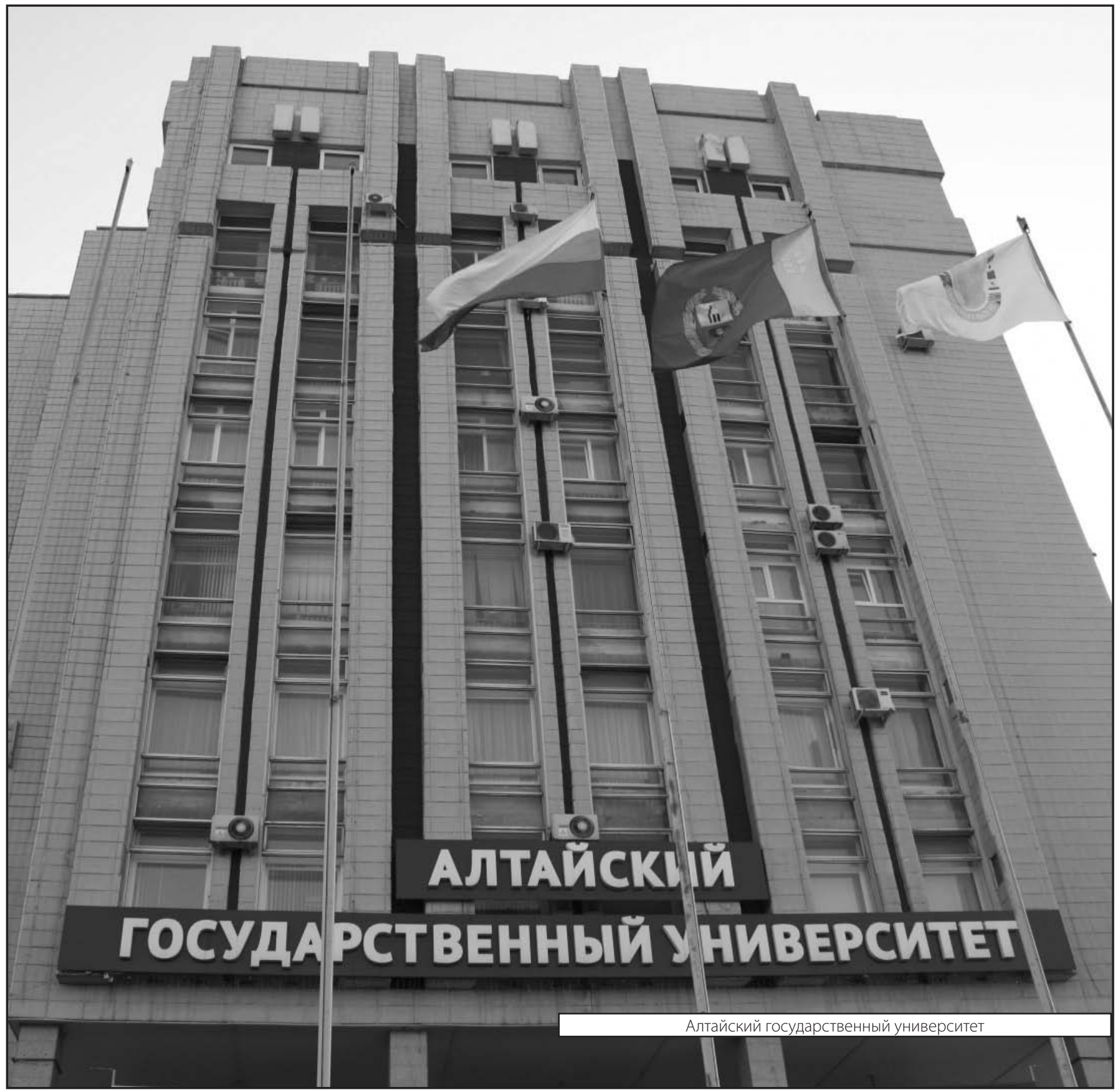

